\title{
EFFECT OF POTASSIUM CHLORIDE AS A LOCAL ANAESTHETIC ADJUVANT FOR SUPRACLAVICULAR BRACHIAL PLEXUS BLOCK FOR UPPER LIMB SURGERIES
}

\author{
Ankla Mahadevappa Shreedhar'1, Borkatte Radesh Hegde², Leela Patel ${ }^{3}$ \\ 1 Junior Resident, Department of Anaesthesiology, Father Muller Medical College, Mangalore, Karnataka. \\ 2 Professor and HOD, Department of Anaesthesiology, Father Muller Medical College, Mangalore, Karnataka. \\ ${ }_{3}^{3}$ Assistant Professor, Department of Biochemistry, Srinivas Institute of Medical Sciences and Research Center, Mangalore.
}

\section{ABSTRACT}

\section{BACKGROUND}

Supraclavicular brachial plexus block is a popular and widely employed regional nerve block technique. It provides safe, effective, low cost anaesthesia along with prolonged post-operative analgesia. Administration of adjuvant along with the local anaesthetic helps in prolonging the pain free period. This study was designed to compare the effect of plain bupivacaine and addition of potassium chloride to bupivacaine in brachial plexus block.

\section{METHODS}

This was a prospective, double blind study in which 60 patients of ASA 1 and 2, aged 20 to 70 years undergoing elective and emergency upper limb surgeries done in Father Muller Medical College Hospital. They were randomly selected and divided into 2 groups to receive $0.375 \%$ bupivacaine with $0.2 \mathrm{mmol}$ of potassium chloride (group- $\mathrm{K}$ ) and 0.375 bupivacaine (group- $\mathrm{B}$ ). Anaesthetist who took no part in brachial block prepared the study drug. Spontaneous breathing was preserved using face mask. The analgesic onset, duration of analgesia, sensory and motor blockade was compared and any adverse event were recorded and treated. Collected data was statistically analysed by student ' $t$ ' test and Chi square test.

\section{RESULTS}

Group-K had a faster onset of sensory and motor blockade, prolonged duration of action than group-B. Quality of blockade was better in adjuvant added group-K.

\section{CONCLUSION}

Potassium chloride as an adjuvant to bupivacaine has advantages in supraclavicular brachial plexus block for upper limb surgeries.

\section{KEYWORDS}

Brachial Block, Bupivacaine, Potassium Chloride, Upper Limb Surgeries, Sensory, Motor, Faster, Duration, Analgesia.

HOW TO CITE THIS ARTICLE: Shreedhar AM, Hegde BR, Patel L. Effect of potassium chloride as a local anaesthetic adjuvant for supraclavicular brachial plexus block for upper limb surgeries. J. Evolution Med. Dent. Sci. 2016;5(15):692-696,

DOI: $10.14260 /$ jemds/2016/160

\section{INTRODUCTION}

Supraclavicular brachial plexus block provides safe, effective, low cost anaesthesia with good prolonged postoperative analgesia. Sensory and emotional experience due to pain has been a major concern of mankind.

Efforts to control pain with adjuvant added to anaesthetics prolongs the pain free period. Intraoperative and postoperatively improves quality of life.

The goals of an anaesthetist are unique in medicine, their purpose is to guide the patients through temporary periods of intense stress with minimal mental and physical harm. Supraclavicular brachial plexus block is a popular and widely employed regional nerve block technique.

Financial or Other, Competing Interest: None.

Submission 10-11-2015, Peer Review 30-01-2016,

Acceptance 08-02-2016, Published 20-02-2016.

Corresponding Author:

Dr. Ankla Mahadevappa Shreedhar

Sampige Sadana, Main Road,

Rajendra Nagar, Shimoga,

Karnataka.

E-mail: aanklasm@gmail.com

DOI: $10.14260 /$ jemds $/ 2016 / 160$
Blockade occurs at the distal trunk, proximal division level. Here, brachial plexus is compact and requires smaller volume of solution to produce rapid onset of reliable blockade. Having distinct advantages over general and intravenous regional anaesthesia, block can be performed with the patients arm in any position. Addition of potassium chloride $4 \mathrm{mmol} /$ litre to isotonic solutions of lignocaine is likely to enhance their clinical effectiveness.(1) The addition of physiological amounts potassium chloride shortens the latency period and prolongs the duration of the blockade.(2)

A regional technique should always be considered whenever general condition of the patient is poor or the patient is not adequately prepared or in the presence of associated conditions like uncontrolled diabetes, cardiovascular or respiratory diseases.

It is also useful when the patient prefers to retain his consciousness during surgery and when it is important for the patient to remain ambulatory. General anaesthetic complications are avoided.

This study was designed to compare the clinical efficacy of the onset, duration, quality of analgesia, quality of sensory and motor blockade and complications of single dose administration using $0.375 \%$ bupivacaine with $0.2 \mathrm{mmol}$ of 
potassium and $0.375 \%$ bupivacaine in brachial plexus block for upper limb surgeries.

\section{OBJECTIVES OF THE STUDY}

1. To determine the time of onset, duration and quality of sensory and motor blockade using $0.375 \%$ bupivacaine $20 \mathrm{ml}$ with $0.2 \mathrm{mmol}$ of potassium in brachial plexus block.

2. To determine the time of onset, duration and quality of sensory and motor blockade using $0.375 \%$ bupivacaine $20 \mathrm{ml}$ in brachial plexus block.

3. To compare the clinical efficacy of the brachial plexus block with $0.375 \%$ bupivacaine $20 \mathrm{ml}$ with $0.2 \mathrm{mmol}$ of potassium and $0.375 \%$ bupivacaine $20 \mathrm{ml}$.

4. To study the adverse effects/side effects if any of $0.375 \%$ bupivacaine $20 \mathrm{ml}$ with $0.2 \mathrm{mmol}$ of potassium and $0.375 \%$ bupivacaine $20 \mathrm{ml}$.

\section{METHODS}

The study entitled "Effect of potassium chloride as a local anaesthetic adjuvant to bupivacaine in brachial plexus block for upper limb surgeries" was conducted in the Department of Anaesthesiology, on the patients posted for elective or emergency surgery with the co-operation of all the surgical departments at Father Muller Medical College Hospital, Mangalore, from January 2015 to May 2015.

\section{Study Type}

Prospective randomised, Double blind study.

\section{Duration of Study}

5 months.

\section{Sample Size}

60 patients selected using purposive sampling technique.

\section{Inclusion Criteria}

1. Patients posted for elective and emergency upper limb surgeries.

2. Age between 20 to 70 years of either sex.

3. ASA grade I or II.

\section{Exclusion Criteria}

1. Patient refusal.

2. Known hypersensitivity to amide local anaesthetics.

3. History of active neurological, cardiac, respiratory and renal diseases.

4. Blood dyscrasias, clotting disorders and platelet count $<100000 / \mathrm{mm}^{3}$

5. Patients with cutaneous infections or anatomical malformation of the spine.

\section{Plan of Study}

A detailed history and pre-anaesthetic evaluation was done previous to the surgery. Routine investigations like haemoglobin, blood grouping, blood urea, blood sugar and platelet count were done. ECG whenever indicated was taken to rule out the presence of any active cardiac disease. Written informed consent was taken prior to scheduled operation from the patient/patient's attendant.
Patients Were Randomly divided into two Groups of $\mathbf{3 0}$ Patients Each

1. Group K - using $0.375 \%$ bupivacaine $20 \mathrm{ml}$ with $0.2 \mathrm{mmol}$ of potassium.

2. Group B - using $0.375 \%$ bupivacaine $20 \mathrm{ml}$.

\section{Technique}

After Institutional Ethical Committee clearance, preanaesthetic evaluation of patients includes detailed examination and necessary investigations were done. Patients were shifted to the operation theatre and pulse oximeter, noninvasive blood pressure and electrocardiography monitors were connected.

Baseline parameters like heart rate, oxygen saturation $\left(\mathrm{SpO}_{2}\right)$ and non-invasive blood pressure were recorded. Intravenous line secured in non-operating limb and intravenous fluid started. Under aseptic precautions, supraclavicular brachial plexus block was given with the patient lying supine with the head turned to opposite side to be blocked and the interscalene groove, where a mark was made approximately 1.5 to $2.0 \mathrm{~cm}$ posterior to the midpoint of the clavicle. Palpation of the subclavian artery at this point confirms the landmark. A 22-gauge, 4-cm needle was directed in a caudad, slightly medial and posterior direction under ultrasound guidance until a paraesthesia or motor response is elicited.

After localization of the brachial plexus, aspiration for blood was performed before injecting local anaesthetic. Multiple injections improve the quality or shorten the onset of blockade. (The probe of ultrasound machine was placed over the supraclavicular region and brachial plexus was identified). The needle makes an angle of $45^{\circ}$ with the table and $15^{\circ}$ with clavicle. The advantage of this first orientation of needle are safety of the situation of the needle tip distant from the pleural dome and subclavian artery.

\section{The Onset and Duration of Sensory Loss and Motor Blockade}

The loss of pinprick sensation was checked every 3 minutes till the onset of loss of sensation and then every 30 minutes till the regain of sensation.

The motor blockade was assessed every 3 minutes till the loss of movements and then every 30 minutes till the regain of movements.

\section{Sensory Block}

The time interval between administrations of local anaesthetic solution to loss of pin prick sensation.

\section{Motor Block}

The time interval between administrations of local anaesthetic solution to loss of movements.

An anaesthetist who took no part in the brachial block prepared the study drug. Spontaneous breathing was preserved using face mask with oxygen.

The analgesic onset time was assessed by a non-harmful pinprick stimulus at the surgical site and repeated every three minutes after the local anaesthetic injection up to the effective blockade.

If there were any related movements or change in heart rate $(>20 \%)$ to the stimuli, pinprick was discontinued. In case of movement or response to the $5^{\text {th }}$ stimuli, the block was 
considered as ineffective and patient was excluded from the study and converted to general anaesthesia.

\section{Vital Parameters}

Heart rate, non-invasive blood pressure and oxygen saturation were recorded every 3 minutes for the first 15 minutes, thereafter every 5 minutes till 30 minutes and every half an hour till the end of the procedure.

Duration of surgery was recorded.

\section{Quality of Sensory Blockade Grading}

0-no analgesia, 1-analgesia with dermatomal sparing, 2-complete analgesia.

\section{Quality of Motor Blockade}

Motor block was graded according to the movement of upper limb by the patient as:

Grade

5 - Normal movement of upper limb,

4 - Movement against resistance,

3 - Movement against gravity,

2 - Movement along gravity, but not against resistance,

1 - Flickering movement, and

0 - No movement.

\section{Duration of Analgesia}

The time between the brachial block and the first analgesic received.
In case of inadequate analgesia during surgery a supplementary bolus of fentanyl $2 \mu / \mathrm{kg}$ IV was administered as an adjuvant.

Any adverse events like arrhythmias, hypotension, convulsions, etc. from the time of pre-medication to brachial block recovery was recorded and treated.

\section{STATISTICAL ANALYSIS}

Quantitative data are presented as mean and standard deviation and qualitative data as frequency and the paired student's test, $\mathrm{x}^{2}$ test or Fisher's exact test will be used for the analysis. Significance was defined as $\mathrm{p}<0.05$. All statistical comparisons were accomplished with statistical package for social sciences (SPSS) 23.

\section{RESULTS AND ANALYSIS}

The present study was done on 60 patients with ASA physical status 1 and 2 selected for the study. They were randomly allocated into two groups of 30 patients each. Group B (bupivacaine $0.375 \%$ ) and group $\mathrm{K}$ (bupivacaine $0.375 \%$ with $0.2 \mathrm{mmol}$ of potassium).

The two groups were compared with respect to age, sex, weight, ASA physical status, ECG change, duration of surgery, haemodynamic variables - heart rate, respiratory rate, systolic blood pressure, oxygen saturation, onset of analgesia, duration of analgesia and requirement of first analgesia.

\section{DEMOGRAPHIC DATA}

1. Gender Distribution

\begin{tabular}{|c|c|c|c|c|}
\hline Sex & Group K & Group B & Total & $\begin{array}{c}\text { Chi square test/Fisher exact } \\
\text { test p value }\end{array}$ \\
\cline { 1 - 3 } Female & $6(20.0 \%)$ & $10(33.3 \%)$ & $16(26.7 \%)$ & \multirow{2}{*}{0.191 NS } \\
\cline { 1 - 3 } Male & $24(80.0 \%)$ & $20(66.7 \%)$ & $44(73.3 \%)$ & \\
\hline Total & $\mathbf{3 0}(\mathbf{1 0 0 . 0} \%)$ & $\mathbf{3 0}(\mathbf{1 0 0 . 0} \%)$ & $(\mathbf{1 0 0 . 0} \%)$ & \\
\hline
\end{tabular}

In both the study groups we included 30 patients, majority were males - 24 in bupivacaine with potassium and 20 in bupivacaine group. The two groups did not show any statistical significance with respect to sex distribution.

\section{ASA Distribution Among the Study Groups}

\begin{tabular}{|c|c|c|c|c|}
\hline ASA & Group K & Group B & Total & $\begin{array}{c}\text { Chi square test/ } \\
\text { Fisher exact test p value }\end{array}$ \\
\hline 1 & $22(73.3 \%)$ & $26(86.7 \%)$ & $48(80.0 \%)$ & \multirow{2}{*}{0.197 NS } \\
\hline 2 & $8(26.7 \%)$ & $4(13.3 \%)$ & $12(20.0 \%)$ & \\
\hline Total & $\mathbf{3 0 ( 1 0 0 . 0 \% )}$ & $\mathbf{3 0}(\mathbf{1 0 0 . 0 \% )}$ & $\mathbf{6 0}(\mathbf{1 0 0 . 0 \% )}$ & \\
\hline
\end{tabular}

There was no statistical significance between the groups with respect to ASA physical status.

\section{Age Distribution}

\begin{tabular}{|c|c|c|c|c|c|}
\hline Group & N & Mean & $\begin{array}{c}\text { Std. } \\
\text { Devia- } \\
\text { tion }\end{array}$ & $\begin{array}{c}\text { Median } \\
\text { (IQR) }\end{array}$ & $\begin{array}{c}\text { t test p } \\
\text { value }\end{array}$ \\
\hline $\begin{array}{c}\text { Group } \\
\text { K }\end{array}$ & 30 & 41.20 & 13.184 & $41(31.25-49.75)$ & 0.155 \\
\hline $\begin{array}{c}\text { Group } \\
\text { B }\end{array}$ & 30 & 46.47 & 15.060 & $47.5(32-58.25)$ & NS \\
\hline
\end{tabular}

Both groups were statistically comparable with respect to age, but did not show any statistically significance.
4. Weight Distribution

\begin{tabular}{|c|c|c|c|c|c|}
\hline Group & N & Mean & $\begin{array}{c}\text { Std. } \\
\text { Devia- } \\
\text { tion }\end{array}$ & $\begin{array}{c}\text { Median } \\
\text { (IQR) }\end{array}$ & $\begin{array}{c}\text { t test } \\
\mathbf{p} \\
\text { value }\end{array}$ \\
\hline $\begin{array}{c}\text { Group } \\
\text { K }\end{array}$ & 30 & 59.30 & 6.390 & $60(55-62.75)$ & \\
\cline { 1 - 4 } $\begin{array}{c}\text { Group } \\
\text { B }\end{array}$ & 30 & 57.53 & 5.686 & $58(52-60.5)$ & $\begin{array}{c}0.263 \\
\text { NS }\end{array}$ \\
\hline
\end{tabular}


The two groups were similar in weight as shown in the above table.

\section{Duration of Surgery}

\begin{tabular}{|l|c|c|c|c|c|}
\hline Group & N & Mean & $\begin{array}{c}\text { Std. } \\
\text { Deviation }\end{array}$ & $\begin{array}{c}\text { Median } \\
\text { (IQR) }\end{array}$ & $\begin{array}{c}\text { t test } \\
\text { p value }\end{array}$ \\
\hline Group K & 30 & 59.33 & 30.250 & $\begin{array}{c}47.5(40- \\
90)\end{array}$ & 0.857 \\
\hline Group B & 30 & 58.17 & 18.217 & $50(50-60)$ & NS \\
\hline
\end{tabular}

There was no statistical significance between the groups with respect to duration of surgery.

\section{Comparison Of Onset Of Sensory And Motor Blockade}

\begin{tabular}{|c|c|c|c|c|c|c|}
\hline $\begin{array}{c}\text { Onset } \\
\text { of } \\
\text { block }\end{array}$ & Group & $\mathbf{N}$ & Mean & $\begin{array}{c}\text { Std. } \\
\text { Deviation }\end{array}$ & $\begin{array}{c}\text { Median } \\
(I Q R)\end{array}$ & $\begin{array}{c}\text { t test } \\
\text { p value }\end{array}$ \\
\hline \multirow{2}{*}{ sensory } & $\mathrm{K}$ & 30 & 10.37 & 1.520 & $\begin{array}{c}10 \\
(9-11)\end{array}$ & 0.0001 \\
\cline { 2 - 7 } & $\mathrm{B}$ & 30 & 24.33 & 3.836 & $\begin{array}{c}27 \\
(23-30)\end{array}$ & $\mathrm{HS}$ \\
\hline \multirow{2}{*}{ motor } & $\mathrm{K}$ & 30 & 9.40 & 1.453 & $\begin{array}{c}9 \\
(8-10)\end{array}$ & 0.0001 \\
\cline { 2 - 7 } & $\mathrm{B}$ & 30 & 21.93 & 3.503 & $\begin{array}{c}25 \\
(20.75- \\
26)\end{array}$ & $\mathrm{HS}$ \\
\hline
\end{tabular}

In group $\mathrm{K}$, the mean onset time of sensory blockade was $10.37 \mathrm{~min}$ and motor blockade was $9.40 \mathrm{~min}$ when compared to group B having sensory onset of $24.33 \mathrm{~min}$ and motor onset of $21.93 \mathrm{~min}$.

\section{Comparison of Duration of Sensory and Motor Blockade}

\begin{tabular}{|c|c|c|c|c|c|c|}
\hline $\begin{array}{c}\text { Duratio } \\
\mathbf{n} \\
\text { of } \\
\text { block }\end{array}$ & $\begin{array}{c}\text { Grou } \\
\mathbf{p}\end{array}$ & $\mathbf{N}$ & Mean & $\begin{array}{c}\text { Std. } \\
\text { Deviati } \\
\text { on }\end{array}$ & $\begin{array}{c}\text { Median } \\
(\mathbf{I Q R})\end{array}$ & $\begin{array}{c}\text { t test } \\
\mathbf{p} \\
\text { value }\end{array}$ \\
\hline \multirow{2}{*}{ sensory } & $\mathrm{K}$ & 30 & 427.52 & 26.579 & $\begin{array}{c}460 \\
(450-490)\end{array}$ & 0.0001 \\
\cline { 2 - 7 } & $\mathrm{B}$ & 30 & 201.43 & 18.134 & $\begin{array}{c}205 \\
(190-220)\end{array}$ & $\mathrm{HS}$ \\
\hline \multirow{2}{*}{ motor } & $\mathrm{K}$ & 30 & 438.83 & 31.415 & $\begin{array}{c}470 \\
(460-\end{array}$ & 0.0001 \\
\cline { 2 - 7 } & $\mathrm{B}$ & 30 & 212.58 & 17.564 & $\begin{array}{c}210 \\
(200-230)\end{array}$ & $\mathrm{HS}$ \\
\hline
\end{tabular}

In group $\mathrm{K}$, the mean duration of sensory blockade was $427.52 \mathrm{~min}$ and motor blockade was $438.83 \mathrm{~min}$ when compared to group B having sensory onset of $201.43 \mathrm{~min}$ and motor onset of $212.58 \mathrm{~min}$.

\section{Quality of Sensory and Motor Block}

\begin{tabular}{|c|c|c|c|c|c|c|}
\hline $\begin{array}{c}\text { Quality } \\
\text { of } \\
\text { block }\end{array}$ & Group & $\mathbf{N}$ & Mean & $\begin{array}{c}\text { Std. } \\
\text { Deviation }\end{array}$ & $\begin{array}{c}\text { Median } \\
\text { (IQR) }\end{array}$ & $\begin{array}{c}\text { t test } \\
\text { p value }\end{array}$ \\
\hline \multirow{2}{*}{ sensory } & $\mathrm{K}$ & 30 & 2.00 & 0.000 & $2(2-2)$ & 0.019 \\
\cline { 2 - 6 } & $\mathrm{B}$ & 30 & 1.83 & 0.379 & $2(2-2)$ & sig \\
\hline \multirow{2}{*}{ motor } & $\mathrm{K}$ & 30 & 0.10 & 0.305 & $0(0-0)$ & $\begin{array}{c}0.050 \\
\text { sig }\end{array}$ \\
\cline { 2 - 6 } & $\mathrm{B}$ & 30 & 0.43 & 0.858 & $0(0-0.25)$ & \multicolumn{2}{|c}{} \\
\hline
\end{tabular}

The quality of sensory and motor blockade was better in group $\mathrm{K}$ and the value was statistically significant when compared with group B.

\section{Adjuvants Used}

\begin{tabular}{|c|c|c|c|c|c|c|}
\hline $\begin{array}{c}\text { Adju- } \\
\text { vant }\end{array}$ & Group & $\mathbf{N}$ & Mean & $\begin{array}{c}\text { Std. } \\
\text { Devia } \\
\text {-tion }\end{array}$ & $\begin{array}{c}\text { Median } \\
\text { (IQR) }\end{array}$ & $\begin{array}{c}\text { t test } \\
\mathbf{p} \\
\text { value }\end{array}$ \\
\hline \multirow{2}{*}{ used } & $\mathrm{K}$ & 30 & 0.00 & 0.000 & $0(0-0)$ & 0.011 \\
\cline { 2 - 6 } & $\mathrm{B}$ & 30 & 0.37 & 0.765 & $0(0-0)$ & sig \\
\hline
\end{tabular}

The group K did not require adjuvant fentanyl $2 \mu \mathrm{g} / \mathrm{kg}$ IV when compared to group B. The p value was $<0.011$, which is significant.

\section{DISCUSSION}

The present study entitled was conducted to assess the effect of using potassium with bupivacaine and plain bupivacaine in brachial plexus block in 60 patients.

It has become evident that satisfactory anaesthesia was made possible by addition of adjuvant to local anaesthetic in brachial plexus block. Brachial plexus block is widely used in upper limb surgeries. Many adjuvants are added to local anaesthetics to improve the quality and duration of blockade.

Fink et al. conducted the study on the significance of impulse conduction in rabbit vagus nerve in vitro, suggested that lack of glucose may reinforce C-fiber in excitability during conduction block and that inclusion of a physiologic amount of potassium chloride in the solution may also be desirable and hastens the onset of blockade.(3)

In our study on sixty patient's age, sex and weight were similar in both the groups. Data was collected and analysed for statistical significance.

Duration of surgery was mean 59.33 min in potassium group compared to 58.17 min in plain bupivacaine group, which was statistically not significant with $\mathrm{p}<0.857$.

In our study the onset of sensory and motor blockade was faster, duration was prolonged in potassium group compared to plain bupivacaine group. With mean onset of blockade $10.37 \mathrm{~min}$ in group $\mathrm{K}$ when compared to $24.33 \mathrm{~min}$ in group B for sensory block. Similarly mean time of $9.40 \mathrm{~min}$ in group $\mathrm{K}$ and $21.93 \mathrm{~min}$ in group B for motor block onset. It was statistically of high significance with $p$ value 0.0001 . The results are consistent with the studies done earlier. These results are consistent with the study of Parris et al.(4) but they had no difference in characteristics of block.

Aldrete JA, et al. showed that the inclusion of $180 \mathrm{mmol}$ potassium chloride nearly doubled the duration of peripheral nerve blockade attainable with $2 \%$ lignocaine.(5) and in McKeown DW, et al. showed no difference was found with the addition of potassium to solution of prilocaine used for intravenous regional anaesthesia.(6)

In our study group $\mathrm{K}$, the mean duration of sensory blockade was $427.52 \pm 26.75 \mathrm{~min}$ and motor blockade was $438.83 \pm 31.41$ min when compared to group B having sensory blockade of $201.43 \pm 18.13 \mathrm{~min}$ and motor blockade of $212.58 \pm 17.56$ min with highly significant $\mathrm{p}$ value $<0.0001$. These results are similar to Khosa DS, et al. study which showed total duration of analgesia by bupivacaine was moderately prolonged in presence of potassium chloride.(7) 
The quality of sensory and motor block was better in group K. In our study, it was clinically as well as statistically significant with $p$ value of 0.019 and 0.050 respectively.

Group K patients did not require analgesia intraoperatively, whereas few in group B received analgesia with significant $p$ value 0.011 .

Addition of potassium to local anaesthetics significantly enhanced the quality of block performed.

Bromage PR, et al. found an early onset of action and a more intense sensory blockade with potassium chloride as adjuvants to lignocaine hydrochloride with adrenaline in epidural blockade, especially in sacral segments which is consistent with our study. (8)

Lanz E, et al. found that brachial plexus block with all four techniques, motor blockade developed faster than sensory blockade. The perineural space enclosing the brachial plexus greatly facilitates the spread of a local anaesthetic when injected. In our study, addition of potassium chloride to bupivacaine developed both sensory and motor blockade faster. ${ }^{(9)}$

The requirement of adjuvant and conversion to general anaesthesia in potassium group is decreased compared to other groups.

\section{CONCLUSION}

This study concludes potassium as an adjuvant to bupivacaine has got several advantages.

Onset of both sensory and motor block is faster, quality is better, duration of sensory and motor blockade is prolonged, the requirement of post-operative analgesia is reduced.
Potassium has significance in onset, quality and duration of sensory and motor blockade in brachial plexus block.

\section{BIBLIOGRAPHY}

1. Kircha S, Barsa J, Fink BR. "Potentiation of nerve block in vivo by physiological adjuvants in the solution." British Journal of Anaesthesia 1983;55(6):549-553.

2. Fink BR, Barsa J, Calkins DF. Osmotic swelling effects on nerve conduction. Anaesthesiology 1979;51:410-423.

3. Fink BR, Calkins DF. Role of glucose or potassium lack in nerve block. Anaesthesiology 1981;55:172-175.

4. Parris MR, Chambers WA. Effects of the addition of potassium to prilocaine or bupivacaine: a double blind comparative study. Br J Anaesth 1986;58:297-300.

5. Aldrete JA, Barnes DR, Sidon MA, et al. Studies on effects of addition of potassium chloride to lidocaine. Anaesthesia and Analgesia 1969;48:269-276.

6. McKeown DW, Scott DB. Influence of the addition of potassium to $0.5 \%$ prilocaine solution during IV regional anaesthesia. Br J Anaesth 1984;56:1167-70.

7. Khosa DS, Thind SS, Gupta HK, et al. Effects of adding potassium chloride to lignocaine and bupivacaine solutions on the onset time and duration of brachial plexus block. Indian Journal of Anaesthesia 1990;38:119122.

8. Bromage PR, Burfoot MF. Quality of epidural blockade. II: influence of physico-chemical factors; hyaluronidase and potassium. Br J Anaesth 1966;38:857-865.

9. Lanz E, Theiss D, Jankovic D. Extent of blockade following various techniques of brachial plexus block. Anaesthesia and analgesia 1983;62:55-58. 